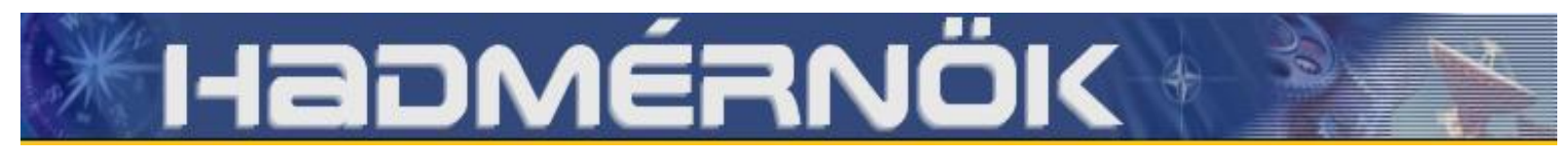

XIV. Évfolyam 1. szám - 2019. március

10.32567/hm.2019.1.12

\title{
SUGÁRÉRZÉKENYSÉGI VIZSGÁLATOK: A KOLÓNIA-KÉPZŐ ASSAY ÉS A COMET-ASSAY PRÓBÁJA
}

\section{RADIATION SENSITIVITY STUDIES: THE TRIAL OF THE COMET-ASSAY AND COLONY-FORMING ASSAY}

\author{
KIS Enikő \\ (ORCID: 0000-0002-6761-0423) \\ kise@osski.hu
}

\begin{abstract}
Absztrakt
Az orvosi gyakorlatban közismert tény, hogy a a sugárterápiára adott biológiai válasz egyénenként eltérő. Számos kutató és szerző foglalkozik az egyéni sugárérzékenység fogalmával, lehetséges gyakorlati következményeivel és kimutatásával. Célszerü lenne hasonló eljárást bevezetni a sugárbalesetek helyszínén, vagy egyéb sugárveszélyes területen bevetésre kerülö katasztrófavédelmi dolgozók és katonák körében is. Jelen tanulmányunkban egyik lehetséges, bár a nemzetközi irodalomban még meglehetösen vitatott szürési módszer alkalmazhatóságát tárgyaljuk.

A szerző ezúton szeretne köszönetet mondani dr. Sáfrány Gézának, MD, PhD, DSc a munka elvégzéséhez és a cikk megírásában nyújtott segítségéért.
\end{abstract}

Kulcsszavak: egyéni sugárérzékenység, katasztrófavédelem, sugárveszélyes környezet, comet-assay, kolónia-képző assay

\begin{abstract}
It is well known, that the biological answer for radiation treatment varies between patients. Many researchers and authors are focusing on the potential practical consequences of individual radio sensitivity. It would be useful to introduce a similar procedure for disaster workers or soldiers who might work in a radiation hazard area. We discuss here a possible, but rather controversial method for screening radiation sensitivity.
\end{abstract}

Keywords: individual radiation sensitivity, disaster management, radiation hazard area, comet-assay, colony forming assay 


\section{A SUGÁRÉRZÉKENYSÉG VIZSGÁLATÁNAK AKTUALITÁSA}

Az első atomerőmü üzembe helyezése óta (1954, Oroszország) a világban 438 atomerőmü müködik. A Csernobil-i (1986) illetve Fukushima-i (2011) katasztrófák elővigyázatosságra intenek. 1940-1999 között 417 sugárbalesetet tartanak számon, amely balesetekben 3003 személy szenvedett sugárterhelést. [1, 178. old.] A Csernobili katasztrófából adódóan 137 olyan személyt tartanak nyilván, akik klinikai tünetet eredményező sugárterhelést kaptak. Az első áldozatok a mentésben résztvevő tüzoltók és az erőmü dolgozói közül kerültek ki. [1, 178. old.; 2, 453. old.]

Legyen tettlegesség vagy baleset, az előre nem tervezett (baleseti) sugárexpozíció lehetősége a radioaktív anyagok orvosi, kísérleti, energetikai vagy katonai felhasználásának szempontjából fennáll.

Egy esetleges katasztrófa esetén kritikusan fontos ismeret lehet a sérülteket kezelő orvos számára a mentési személyzet egyéni sugárérzékenysége, amely jelentősen befolyásolhatja az adott egyén sugárhatásra adott válaszát, a sugársérülést követő felépülésének folyamatát. Hosszú távon szeretnénk olyan, minimálisan invazív mintavétellel járó, gyorsan kivitelezhető szürési eljárást kidolgozni, amely lehetővé teszi, hogy felmérhessük a sugárszövődmények kialakulásának veszélyét egyrészt a kórházi sugárkezelésre szoruló betegekben, másrészt a sugárveszélyes környezetben dolgozókban is. Ezáltal például a radiológusok, a katonák, tüzoltók sugárérzékenysége akár az alkalmassági vizsgálat részeként is felmérhetővé válna.

\section{AZ EGYÉNI SUGÁRÉRZÉKENYSÉG ÉS A COMET-ASSAY}

A sugárterápiára kerülő betegekben a kezelés megkezdése előtt elvégzett egyéni sugárérzékenység felméréséből következtetni lehetne a korai és késői sugárterápiás szövődmények kialakulásának az esélyére. A várható kockázatok ismerete a beteg sugárterápiájának egyéni kialakítását is lehetővé tenné.

A sugárterápiával kezelt betegek mintegy 5-10\%-ában alakulnak ki súlyos korai, illetve késői sugárszövődmények a nem daganatos sejtek extrém sugárérzékenysége, illetve fokozott elhalása miatt. A lehetséges mellékhatásokat a börpírtól a teljes szöveti nekrózison keresztül a genetikai instabilitásig különböző osztályozási rendszerekbe sorolják. Leggyakoribb a korai és késői mellékhatásokra való tagolás. A korai mellékhatások közé sorolják például a bőrpírt, mucositis-dermatitiszt, hajveszteséget, míg késői mellékhatás lehet teleangiektázia ${ }^{1}$, vagy fibrózis ${ }^{2}$. [3, 103. old.] Irodalmi adatok alapján az egészséges szövetekben kialakuló korai és késői sugárterápiás szövődmények kockázata felbecsülhető a betegekből származó fibroblaszt ${ }^{3}$ és limfocita sejtek sugárérzékenységének vizsgálatával. [4, 125-126. old.; 5, 613. old.] Ez a két sejttípus a szervezet minden pontján előfordul, ráadásul a limfociták begyüjtése vérvétel útján alacsony invazivitású folyamat.

A fenti premisszák alapján az egyéni sugárérzékenységgel kapcsolatos vizsgálatok legmegfelelőbb alanyai jelenleg a sugárterápiára kerülő betegekből származó sejtek, illetve szövetminták. Ennek oka, hogy mivel ezek a sejtek a kezelt terület közelében helyezkednek el, a teljes radioaktív kezelés időtartama alatt a pontosan ismert és jól dokumentált dózisú sugárnyaláb útjába kerülnek. A betegek sugárzásra adott reakciói a továbbiakban nyomon követhetőek a klinikai monitorozásnak köszönhetően.

\footnotetext{
${ }^{1}$ hajszálerek tartós kitágulása

${ }^{2}$ fibrózis: adott szövet elpusztult sejtjeit fibrociták helyettesítik - hegesedés

3 a legáltalánosabban előforduló kötőszöveti sejt
} 
A sugárzás hatására keletkező DNS lánctörések száma állandó az adott dózisra a sejt típusától és sugárérzékenységétől függetlenül. ${ }^{4}$ Az egyes sejtek és egyedek sugárkárosodással szemben való ellenállása ezen törések kijavításának minőségéből, valamint időtartamából adódik. Ha a károsodott sejt nem tudja kijavítani a DNS-ében az ionizáló sugárzások által létrehozott egy- vagy kétláncú töréseket, elpusztul. Az emberi sejtek pusztulásának egyik leghatékonyabb in vitro ${ }^{5}$ nyomon követése kolónia-képző assay segítségével lehetséges. [4, 126. old.]

Az egyéni sugárérzékenység tehát összefüggésben van a sejtek DNS javító képességével. Az egyén sorsára nézve végső soron a sejtekben lévő DNS-javító (repair) enzimek szintje, az őket kódoló génekben esetleg jelenlevő mutációk, illetve az adott sejt osztódási állapota, a sérült DNS kijavítására rendelkezésre álló idő meghatározó lesz. Ez utóbbit a sejtciklus szabályozásában szerepet játszó különböző fehérjék számottevően befolyásolják. [1, 110-111. old.; 6, 932.old.; 7, S14-15. old.]

Feltételezhető tehát, hogy amennyiben mérni tudnánk a sejtek DNS javításának hatékonyságát, a javítás nyomán visszamaradó DNS-törések mennyiségét és ezek egyének közötti eltérését, valamint be tudnánk bizonyítani, hogy mindez összefüggésben van az esetleges klinikai mellékhatások előfordulásával az illető személyben, egyszerủen és gyorsan kezelhető módszert tudnánk kidolgozni a sugárzásra adott egyéni reakció szürésére. Erre alkalmas módszer az egy-sejt elektroforézis vagy comet-assay, melynek segítségével a sugárkezelés következtében keletkező, illetve bizonyos idő elteltével hátramaradó, még töredezett DNS mennyiségét lehet az egyes sejtek szintjén kimutatni. [8, 190. old.; 9, 206-221. old.]

A nemzetközi orvosbiológiai folyóiratokban megjelent cikkek egy része szerint a különböző dózisokkal besugarazott sejtekben visszamaradó ú.n. reziduális DNS törések mennyisége összefüggésben van az egyéni sugárérzékenységgel. [4, 126-128. old.; 11, 931-936.old.; 12, 284-287. old.; 13, 645. old.; 15, 85. old.] Munkánk célja hosszú távon az egyéni sugárérzékenység felmérése még a sugárterápia megkezdése előtt a kórházi betegekben, másrészt alkalmassági vizsgálatként egy esetleges radiológiai vagy nukleáris incidenst követő helyszíni helyreállító munkálatokon dolgozó katonák és katasztrófavédelmi munkások körében. Ezen tanulmányban a kolónia képző assay valamint a comet-assay, mint lehetséges sugárérzékenység-kimutató módszer alkalmazhatóságát vizsgáltuk egy daganatos betegpopuláción.

\section{MÓDSZEREK}

\section{Betegcsoportok}

A vizsgálatok során 123 sugárterápiás betegből vettünk biológiai mintát (vérmintát és bőrbiopsziát) és azokat maradéktalanul feldolgoztuk. A vizsgálatokhoz felhasznált biológiai minták túlnyomó többségét Prof. Dr. Ésik Olga, Országos Onkológia Intézet, Budapest, bocsátotta rendelkezésünkre. (etikai engedély: ETT TUKEB 6008/1/ETT/2002). A betegekböl származó bőr-biopsziás mintákból primér fibroblaszt-sejtkultúrákat indítottunk és klonogénassay-vel mértük a fibroblasztok sugárérzékenységét. A fibroblasztok sugárérzékenységének további analízisére bevezettük a comet-assayt, amely lehetőséget nyújtott a repair-kapacitásuk mérésére is. A vérmintákat in vitro körülmények között besugaraztuk és a sejtek DNS-repair

\footnotetext{
${ }^{4}$ 1Gy kis LET értékű sugárzás 1000 db egyláncú 40 db kétláncú törést okoz a DNS-ben [1, 58. old.]

${ }^{5}$ laboratóriumi körülmények között, sejt-tenyésztéssel történő kísérletek
} 
képességét mértük comet-assay-vel. Az eredményeinket statisztikai programok segítségével a betegek fibroblasztjainak sugárzásra adott in vitro túlélési arányával, valamint in vivo az egyéni klinikai sugárérzékenységével vetettük össze.

A kontroll csoportba kezelés előtt álló sugárterápiás betegeket, valamint egészséges gyerekek fitymáiból származó primér fibroblasztokat soroltunk $(\mathrm{K})$. A másik mintavételi csoportba olyan, már sugárterápiában részesülő betegek kerültek, akik bár felépültek a daganatos betegségükből, a sugárterápia következtében a sugármező által befogott területen toxikus reakciójuk alakult ki. Ezeket a betegeket további négy csoportba soroltuk:

- emlődaganatos betegek, akikben bőrfibrózis vagy teleangiektázia alakult ki (64 minta).

- toxikus késői idegrendszeri tüneteket mutató betegek (18 minta).

- olyan betegek, akikben a sugárterápia következtében mucositis/dermatitisz alakult ki (14 minta).

- olyan, vegyes betegcsoport (21 minta), amelyben az eddig említettektől eltérő toxikus sugárreakciók alakultak ki.

\section{Sejttenyésztés és sugárkezelés}

\section{Primér fibroblaszt kultúra kialakítása}

Fibroblaszt-sejtkultúra kialakítása céljából a bőrmintákat apró, 0,5x0,5mm-es darabkákra vágtuk, majd antibiotikumot tartalmazó PBS-pufferben mostuk. A bördarabkákat $25 \mathrm{~cm}^{2}$ felületü tenyésztő edénybe tettük és $1,5 \mathrm{ml} 40 \%$ fötális borjú-szérumot tartalmazó Dulbecco's Modified Médiumot (DMEM) ${ }^{6}$ adtunk, amely a bőrdarabkák letapadását szolgálta. Ezt követően a médiumot $5 \mathrm{ml}$ térfogatra és $20 \%$ szérumtartalomra egészítettük ki. Körülbelül tíz nappal a bőrdarabkák letapadása után jelennek meg a környező területen a fibroblasztok, amelyek további 1-2 hét múlva begyüjthetők és tovább olthatók. A primer fibroblasztkultúrákat 20\% szérum tartalmú DME-médiumban tartottuk fent.

A fibroblasztokat $10 \%$ FBS tartalmú DMEM tápban $5 \% \mathrm{CO}_{2}$ tartalmú légkörben $37^{\circ} \mathrm{C}$-on tenyésztettük, majd a teljes konfluencia elérése után sugárkezeltük. A sugárkezelést 1-, 2-, 4valamint $6 \mathrm{~Gy}{ }^{60} \mathrm{Co}-\gamma$ sugárzással végeztük (Gammatron-3 Siemens, Erlangen, Németország).

A primer fibroblasztok használatának hátránya, hogy kb. 2-3 hétig tart a sejtkultúra kialakítása. Mivel a fehér vérsejtek sugárérzékenysége szintén vizsgálható alkálikus és neutrális comet-assay-vel, a vérminták begyüjtése pedig egy egyszerü és alacsony invazivitású folyamat, úgy döntöttünk, hogy az azonos betegek vérmintáin is vizsgáljuk az in vitro sugárérzékenységet, összevetve azt a klinikumban mért sugárterápiára adott válasszal.

\section{Vérminták}

A vérmintákat a vérvételt követően 3 órán belül in vitro sugaraztuk be 2 Gy dózisú, 60 Co- $\gamma$ sugárzással (Gammatron-3 Siemens, Erlangen, Németország). Közvetlenül a besugárzást követően lúgos és semleges comet-assay-vel mértük a DNS-törések gyakoriságát. A DNSrepair-kapacitás nyomon követésére a besugarazott vérmintákat $5 \% \mathrm{CO}_{2}$ tartalmú légkörben $37^{\circ} \mathrm{C}$-on négy órát inkubáltuk, és ezt követően ismételten elvégeztük a comet-assay-t.

\footnotetext{
${ }^{6}$ a humán sejtek laboratóriumi körülmények között történő tenyésztéséhez használatos oldat.
} 


\section{Klonogén assay}

A primer sejtkultúrák kialakítása után meghatároztuk a fibroblasztok regenerálódó képességét. A sugárérzékenység vizsgálata során $100 \mathrm{~mm}$ átméröjü Petri- csészére 500-1500 sejtet oltottunk ki. Tizenkét órával később a sejteket $0,5-; 1$-, 2- és $4 \mathrm{~Gy}$-vel sugárkezeltük $\left(\mathrm{Co}^{60}-\gamma\right)$ majd kolónia képző-assay-vel követtük nyomon a sejtek túlélését. Amennyiben egy sejt túlél és osztódik, sejt-kolóniák jönnek létre, amelyek metanolos fixálást és CBB R-250 festést követően szabad szemmel is láthatóvá válnak. A túlélő sejtek frakcióját százalékosan fejeztük ki. A sejtek egy részében csak a $2 \mathrm{~Gy}$ besugárzást túlélő frakciót (surviving fraction at $2 \mathrm{~Gy}=\mathrm{SF} 2$ érték) határoztuk meg. (1. ábra)

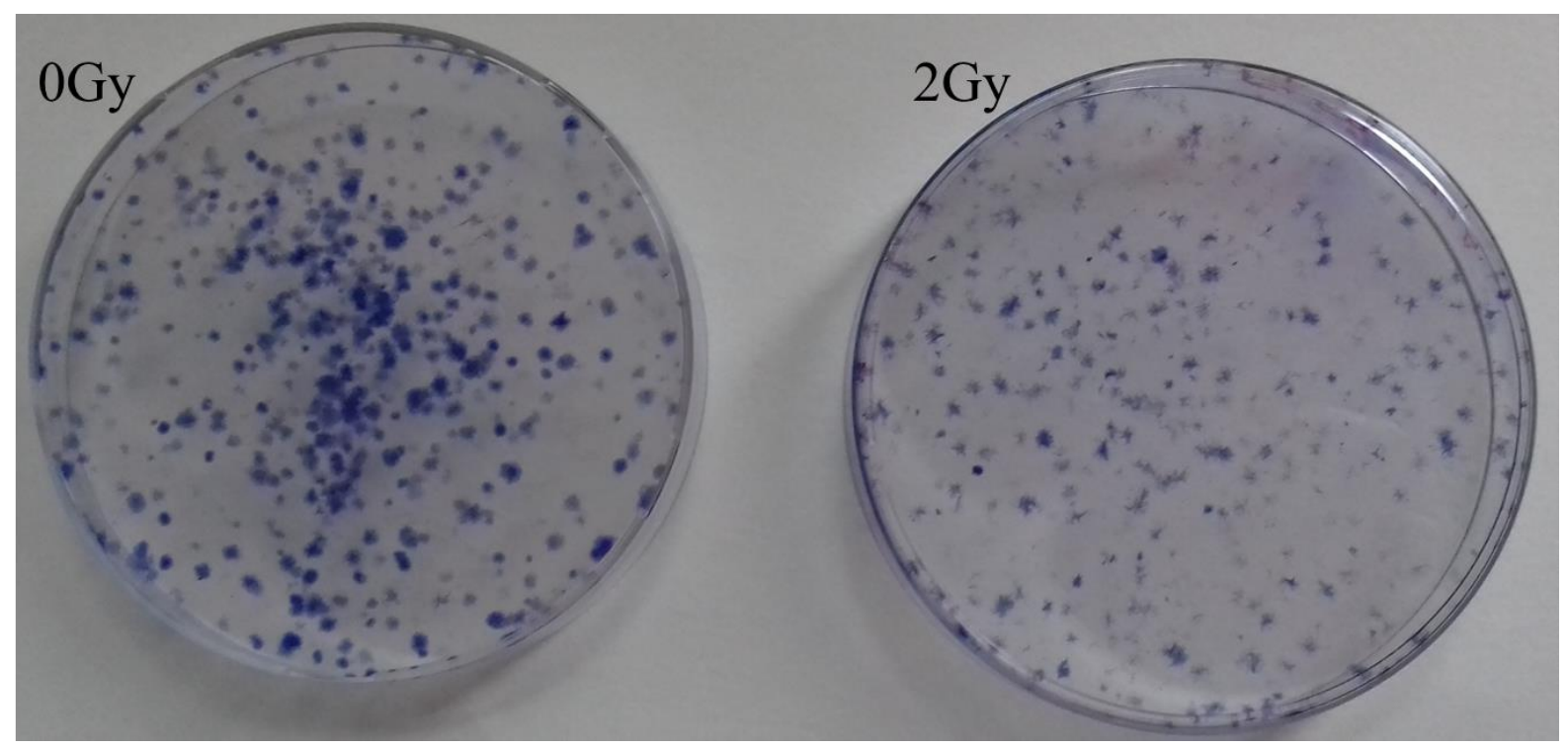

1. ábra kezeletlen kontroll (0Gy), illetve 2Gy-vel sugárkezelt fibroblasztok kolóniái. (saját fotó)

\section{Comet-assay}

A klonogén assay hátránya, hogy a besugárzás után kb. két hét múlva kapunk csak eredményt. Ezért szerettük volna bevezetni egy gyorsabb módszer, az alkálikus és a neutrális egy-sejt elektroforézis (comet) assay használatát is az egyéni sugárérzékenység vizsgálatára.

A DNS törések nagy mennyisége, illetve a repair elégtelensége a sejtet különböző molekuláris útvonalak irányába tolja el, amelyek a sejt pusztulásához vezetnek. A comet-assay vagy egy-sejt gél-elektroforézis segítségével kimutathatók a sugárzás hatására keletkező, illetve a javítás hiányossága miatt bizonyos idő elteltével visszamaradó egy- és kétláncú törések is. A két adat különbségéből a sejtek DNS javító képességére lehet következtetni.

A comet-assay során a sejtkultúrában növő fibroblasztokat a teljes konfluencia állapotában sugárkezeltük. A sejttenyésztő flaskákban besugarazott sejtek egy részét a sugárkezelést követően azonnal letripszineztük és 0,5\%-os lágy agarba (LMPA) ágyaztuk, ezt követően pedig $1 \%$ triton-x100 és 10\% DMSO tartalmú oldatban éjszakán át lizáltuk. Ezután az egy láncú DNS törések vizsgálatához a lemezeken rögzített sejtek DNS láncát erősen alkáli pH-jú (0,3M-os $\mathrm{NaOH}, \mathrm{pH}>13$ ) pufferben 30 percen keresztül szobahőn denaturáltuk. Az elektroforézist $25 \mathrm{mV}$ feszültségen és $300 \mathrm{~mA}$ áramerősségen folytattuk le. (2. ábra) A kétláncú törések elektroforetikus kimutatásához szükséges $1 \mathrm{mV} / \mathrm{cm}$ feszültséget 1,81 térfogatú, neutrális $\mathrm{pH}$-jú 
(TBE, pH: 8,3) puffer oldat segítségével értük el. (3. ábra). ${ }^{7}$ [8, 9 nyomán kidolgozott módszer.] A DNS repair-kapacitás nyomon követésére a besugarazott minták hátralévő részét $37^{\circ} \mathrm{C}$-on és $5 \% \mathrm{CO}_{2}$-t tartalmazó környezetben négy órát inkubáltuk, ezt követően pedig ismételten elvégeztük a comet-assay-t.

Az eljárás alapja az, hogy az elektroforézis során a sejtmagban lévő DNS az anód felé vándorol. A DNS fragmentumok elmozdulása elsősorban a súlyuktól függ, ez esetben pedig a sugárzás hatására a benne keletkező törések számától. Az ép, illetve a töréseket nem tartalmazó nagy molekulasúlyú DNS a magban marad és az elektroforézis után ez adja az üstökös (comet) magját. A sugárzás hatására összetört DNS pedig a comet csóváját alakítja ki. A magban és a csóvában jelenlévő DNS-mennyiség aránya adja meg a DNS-károsodás mértékét. A neutrális közegben végzett elektroforézis kizárólag a kétláncú DNS törések vizualizására alkalmas. Az alkálikus comet-assay segítségével az egy- és kétszálú törések egyaránt kimutathatóak. [16, 951-955.old.]

A kiértékelés etídium-bromidos festést követően, Zeiss fluorescens mikroszkóppal, a Kinetic Imaging Comet4 számítógépes szoftverének segítségével történt.

a.)

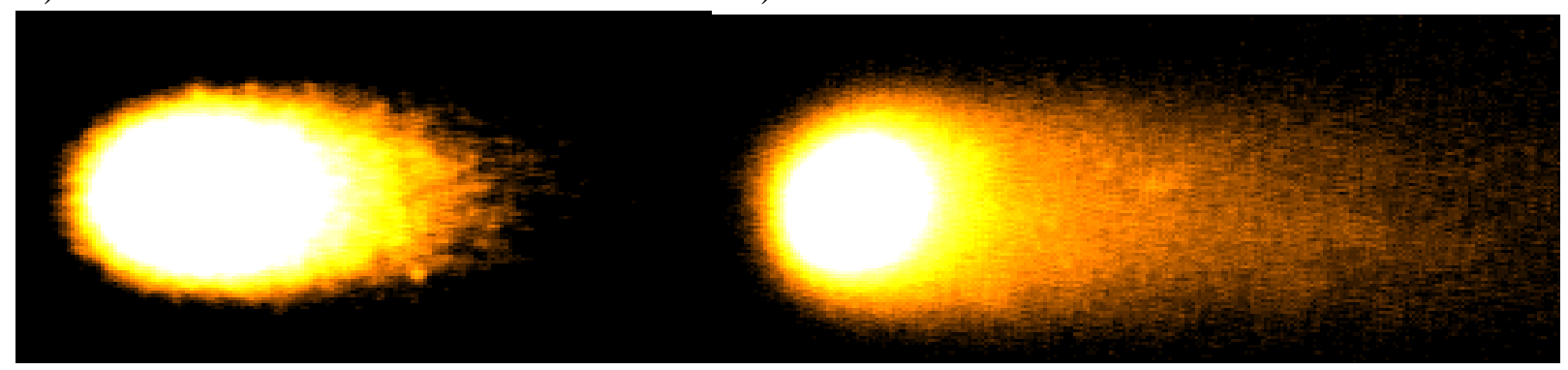

2. ábra Egyláncú DNS törések besugarazatlan (a) és besugarazott sejtekben (b). A fényképeken az erős fényes folt az eredetileg a sejtmagban található DNS, a mögötte elhúzódó darabok az elektroforézis során elvándorolt, sérült DNS. (etídium-bromidos festés, saját fotó)

a.)

b.)

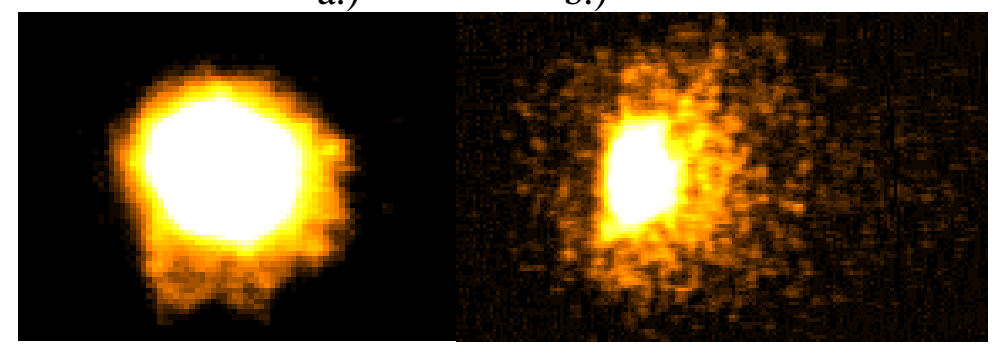

3. ábra Kétláncú DNS törések besugarazatlan (a) és besugarazott sejtekben (b). A fényképeken az erős fényes folt az eredetileg a sejtmagban lévő DNS, a mögötte elhúzódó darabok az elektroforézis során elvándorolt, sérült DNS. (etídium-bromidos festés, saját felvételek)

A kiértékelés során a Comet4 program által felajánlott paraméterek közül az Olive Tail Moment (OTM), valamint a Tail Factor-t használtuk fel, az eredményeket Excel Macros és Excel programokkal értékeltük ki. [14] Az OTM egy globális comet-paraméter: egyaránt

\footnotetext{
${ }^{7}$ A saját laboratóriumi körülményeink között (elektroforézis tálca alakja) a futtató puffernek ezen térfogata adta a megfelelő feszültséget.
} 
figyelembe veszi a töredezett DNS mennyiségét és a nucleoidtól való eltávolodásának mértékét, míg a Tail Factor a tulajdonképpeni töredezett DNS százalékos arányát fejezi ki az alábbi képletek alapján:

OTM $=[($ csóva átlaga - mag átlaga $)$ x a csóvaDNS \%/100]

Tail Factor $=$ Tail DNA = a csóvában található DNS-százalék átlaga.

\section{EREDMÉNYEK}

\section{Primer fibroblasztok sugárérzékenységének vizsgálata klonogén-assay-vel}

A Módszerek fejezetben leírt csoportokból származó primer fibroblasztok túlélését határoztuk meg in vitro besugárzás után. Mint említettük, a kontroll csoport két részből állt. Az egyiket az egészséges gyerekek fitymáiból származó primer fibroblasztok képezték. Itt a túlélési görbék lefutása egy igen szük tartományba esett. A másik kontroll csoport a sugárterápia előtt álló betegeket tartalmazta. E betegekből származó fibroblasztok in vitro sugárérzékenysége megegyezett az egészséges gyerekek fibroblasztjainak sugárérzékenységével. Az összesített kontroll csoport SF2 értékeinek megoszlását az 1. grafikon szemlélteti. A kontroll betegcsoportból származó minták SF2 értékei a 20-50\%-os túlélési tartományba esnek.

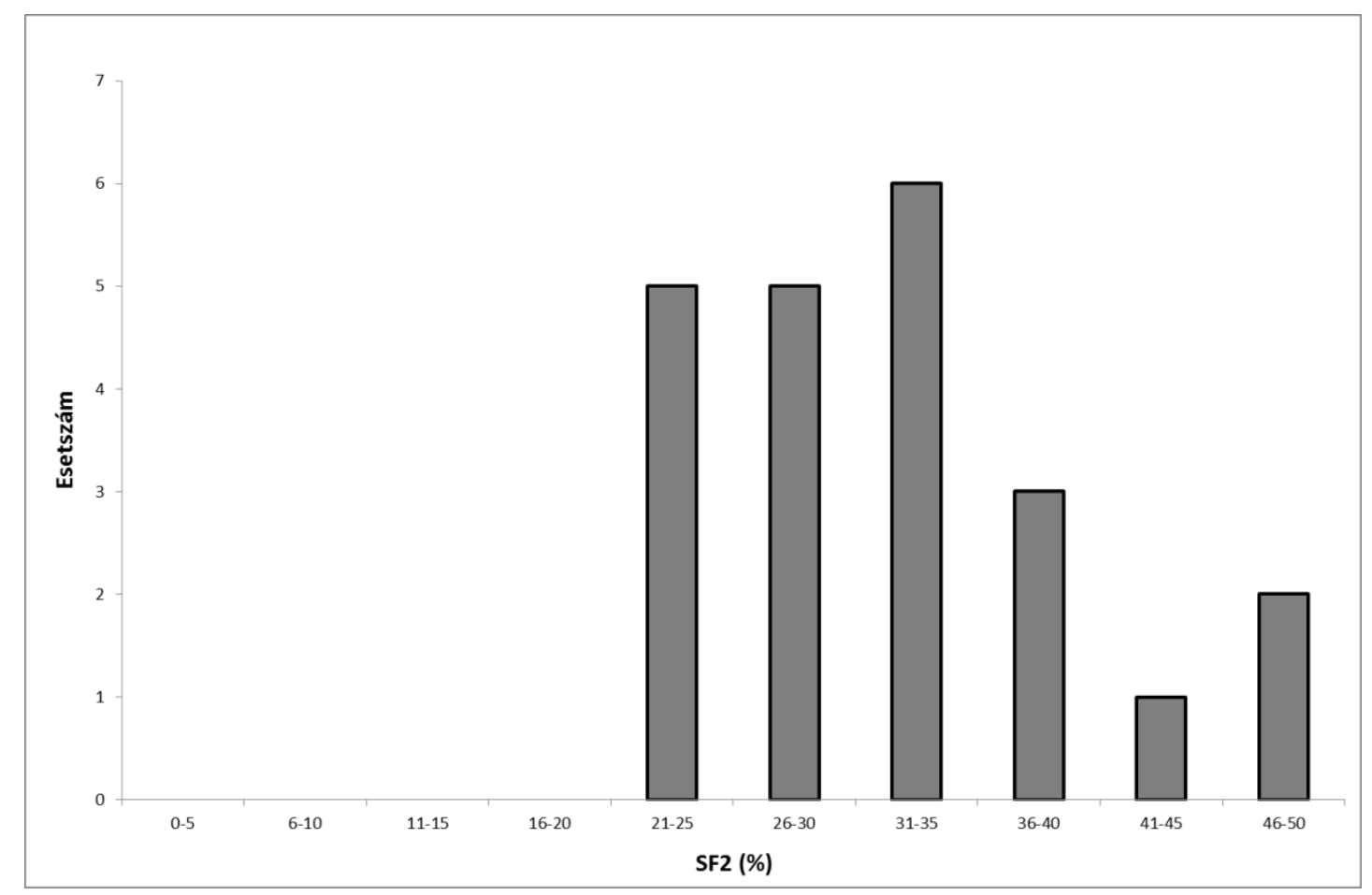

1. grafikon Kontroll betegek SF2 értékeinek eloszlása. A kontroll betegek sejtjeinek 20$50 \%$-a éli túl a 2 Gy dózisú sugárkezelést.

Sikerült igen jelentős számú mintát (mind vér, mind pedig bör biopszia) nyernünk olyan betegekből, amelyekben a sugárterápia következtében már valamilyen korai vagy késői toxikus sugár-reakció kialakult. Ezeket a betegeket tüneteik alapján a Módszerek fejezetben már említett négy nagy csoportba osztottuk.

Azokban a betegekben, amelyekben a sugárterápia következtében valamilyen idegrendszeri mellékhatás alakult ki, az SF2-értékek balra, azaz a sugárérzékeny frakciók felé tolódtak el, négy beteg esetében pedig a fibroblasztoknak mindössze 6-15\%-a élte túl a 2 Gy sugárkezelést (2. grafikon). 


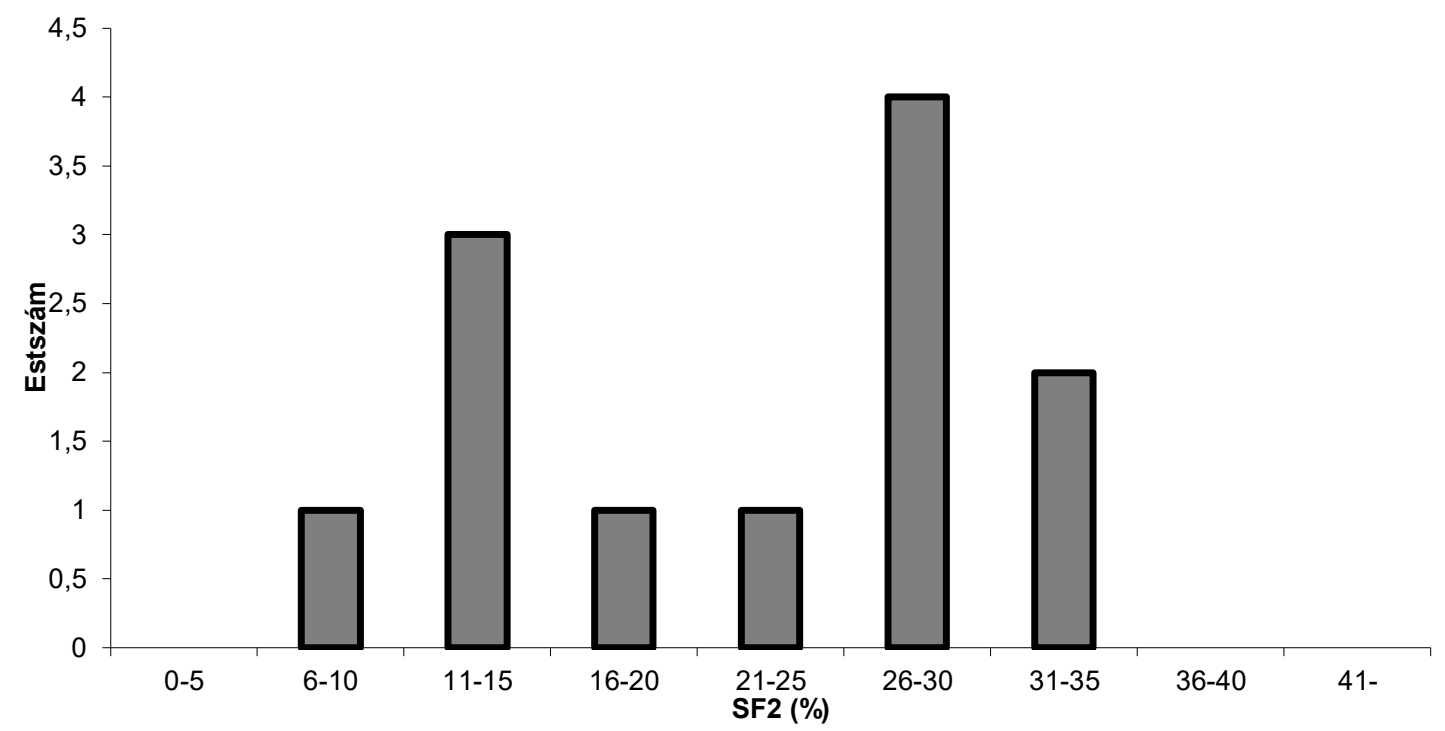

2. grafikon Idegrendszeri mellékhatásokkat elszenvedő betegek fibroblasztjainak $\mathrm{SF}_{2}$ értékei. Látható, hogy a betegek körülbelül felének a fibroblasztjai gyengébb túlélést mutatnak, mint a kontroll betegcsoporté.

A következő betegcsoportba olyan betegek tartoztak, amelyekben a külső sugár- és/vagy brachyterápia következtében börrendszeri és subcutan szöveti mellékhatások alakultak ki. E betegcsoport SF2-értékei mérsékelten térnek el a kontroll csoportétól (3. grafikon).

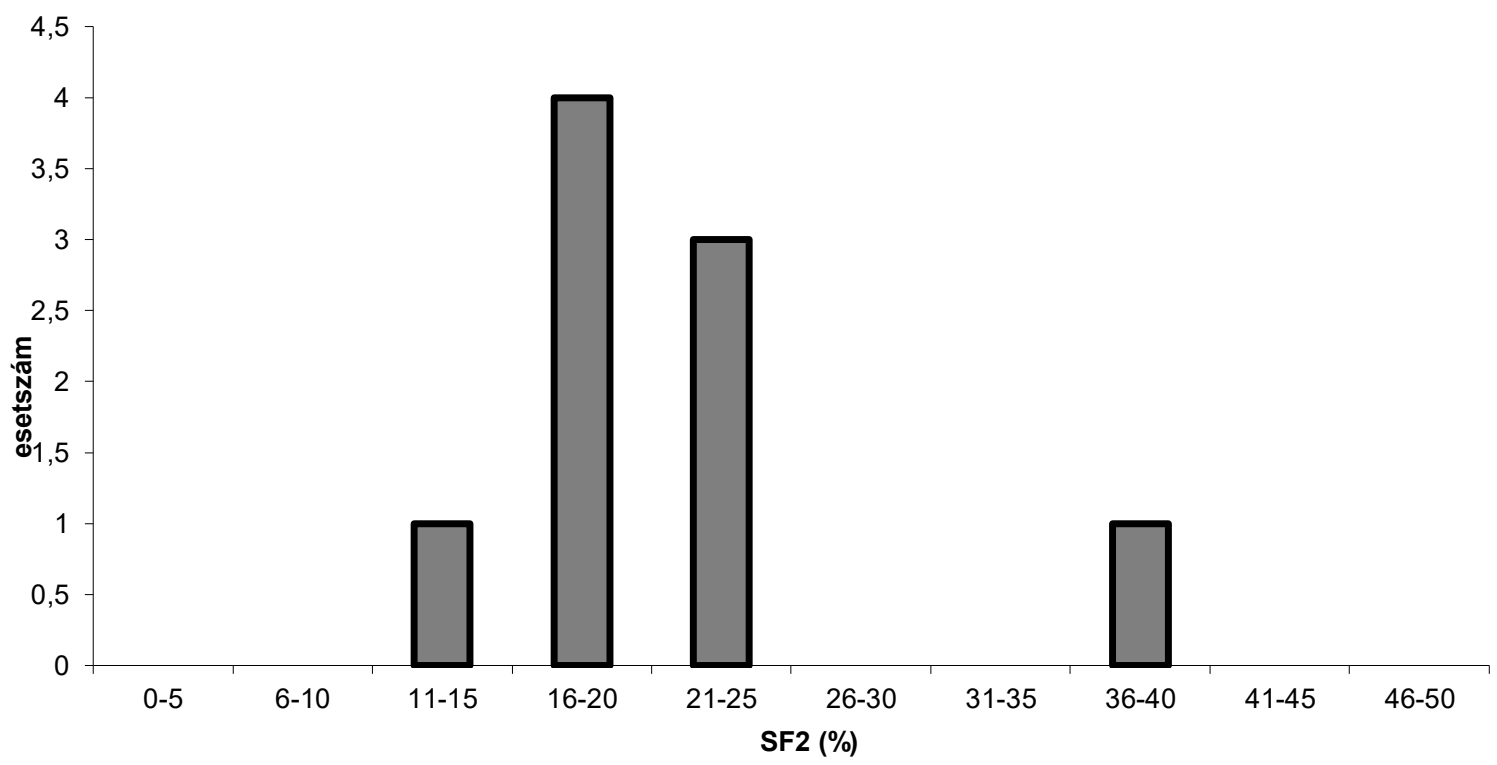

3. grafikon Sugárhatásra mucositis-dermatitiszes mellékhatásokat mutató betegek $\mathrm{SF}_{2}$ értékei.

A 4. grafikon emlödaganatos betegek fibroblasztjainak túlélését mutatja be. A grafikonon látható, hogy e betegek túlnyomó többségének a fibroblasztjai a kontroll csoportéhoz hasonlóan 20-45\%-ban élték túl a sugárkezelést, mindössze 11 beteg sejtjeinek a túlélése volt $20 \%$ alatti. Ez egy, a klinikai mellékhatások szempontjából is nagyon vegyes betegcsoport volt, amelyben egyaránt voltak olyan betegek, akiknek súlyos sugárzás okozta mellékhatásai voltak és olyanok is, akik meglehetősen jól viselték a sugárterápiát. Ennek ellenére nem sikerült korrelációt kimutatnunk a klinikai sugárérzékenység és az in vitro sugárérzékenység között. 


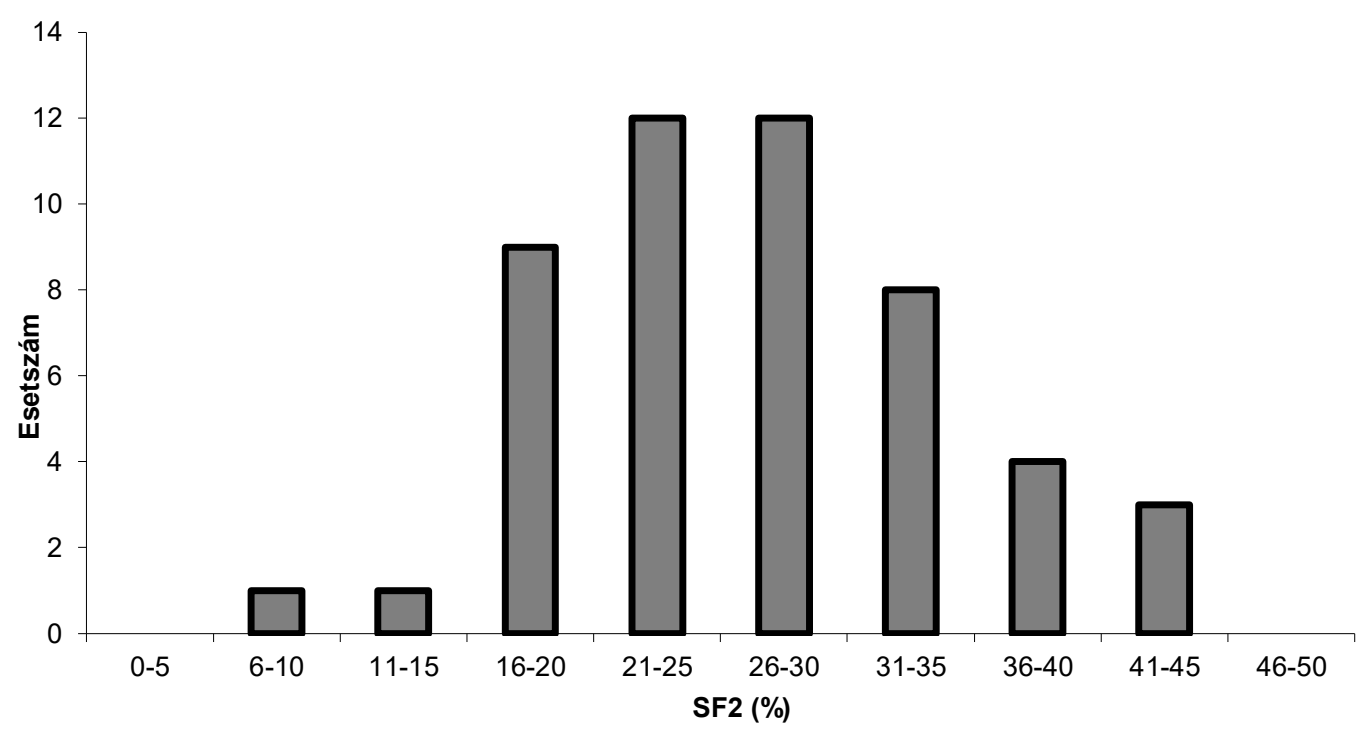

4. grafikon Emlődaganatos betegekböl származó fibroblasztok $\mathrm{SF}_{2}$ értékei

\section{Alkálikus és neutrális comet-assay alkalmazása fibroblasztok sugárérzékenységének mérésére}

A klonogén assay segítségével tulajdonképpen a sejtek sugárzás-okozta károsodásainak kijavítódása után lehet mérni azok túlélését, amely végső soron a sejten belüli folyamatok eredménye. Az egyes fibroblaszt-sejtek sugárzás okozta DNS károsodásainak és azok repairjének a vizsgálatát elvégeztük alkálikus és neutrális comet-assay-vel is. Előszőr azonban tanulmányoztuk a DNS károsodás dózistól való függését (0,5 - 6Gy), majd pedig a DNS törések kijavítódásának időbeli folyamatát $(0,10,20,30,60,120,240$ perc).

A sugárzás hatására keletkező DNS lánctörések száma a sejt típusától és sugárérzékenységétől függetlenül állandó egy adott dózisú sugárkezelést követően, viszont a dózis függvényében nő. Az 5. grafikonon látható, hogy a kétláncú DNS törések következtében keletkező DNS fragmentumok a dózis emelkedésével arányosan egyre nagyobb mennyiségben mutathatók ki (tail DNA): a besugarazatlan kontroll mintában a csóva mag felöli részén tömörül a DNS, míg a 6 Gy-el kezelt sejtek esetén a csóva sejtmagtól távolabb eső részére csoportosul át, ami a jelentős mennyiségű DNS törésnek köszönhető. 


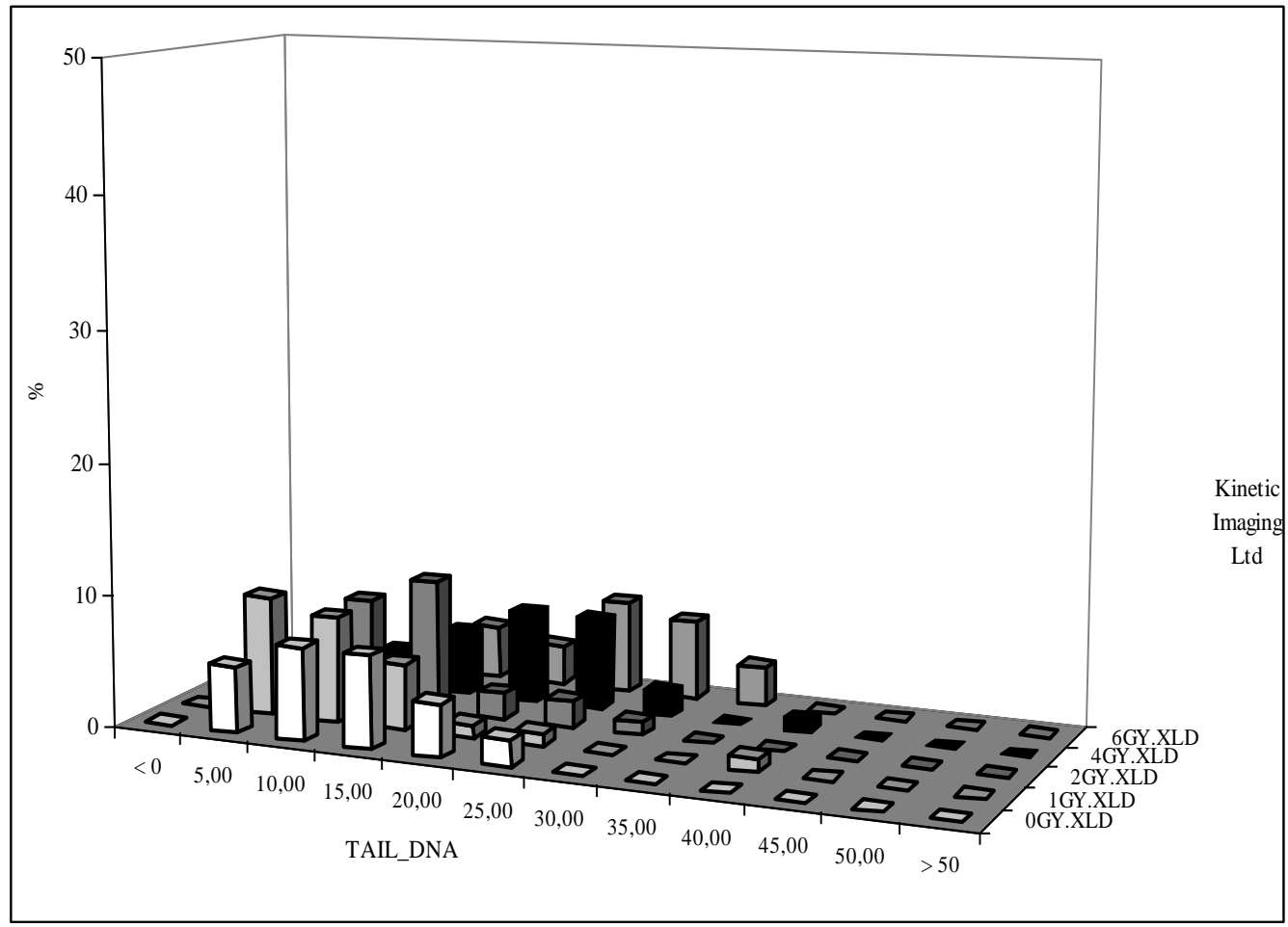

5. grafikon Kétláncú törések következtében kialakuló DNS fragmentumok eloszlása különböző dózisok függvényében, fibroblasztokban. Az első sorban a kezeletlen kontroll, majd egymást követően az 1-, 2-, 4- és 6 Gy dózissal besugarazott fibroblasztokban keletkező kétláncú DNS törések mennyiségét tüntettük fel Kinetic Imaging program segítségével. Az egyre nagyobb számú törés következtében egyre nagyobb mennyiségü DNS vándorol ki a sejtmagból.

A továbbiakban vizsgáltuk a törések keletkezésének és kijavítódásának időbeli dinamikáját a kezelést követő 30 perccel, 1-,2-, 4- és 24 órával. A legmagasabb töredezettségi értékeket a sugárkezelést követő egy órán belül mértük. A sejtben végbemenő javító folyamatoknak köszönhetően a DNS törések száma és eloszlása a sugárkezelést követően mindössze 4 órán belül visszacsökken a kontroll értékekre (6. grafikon). 


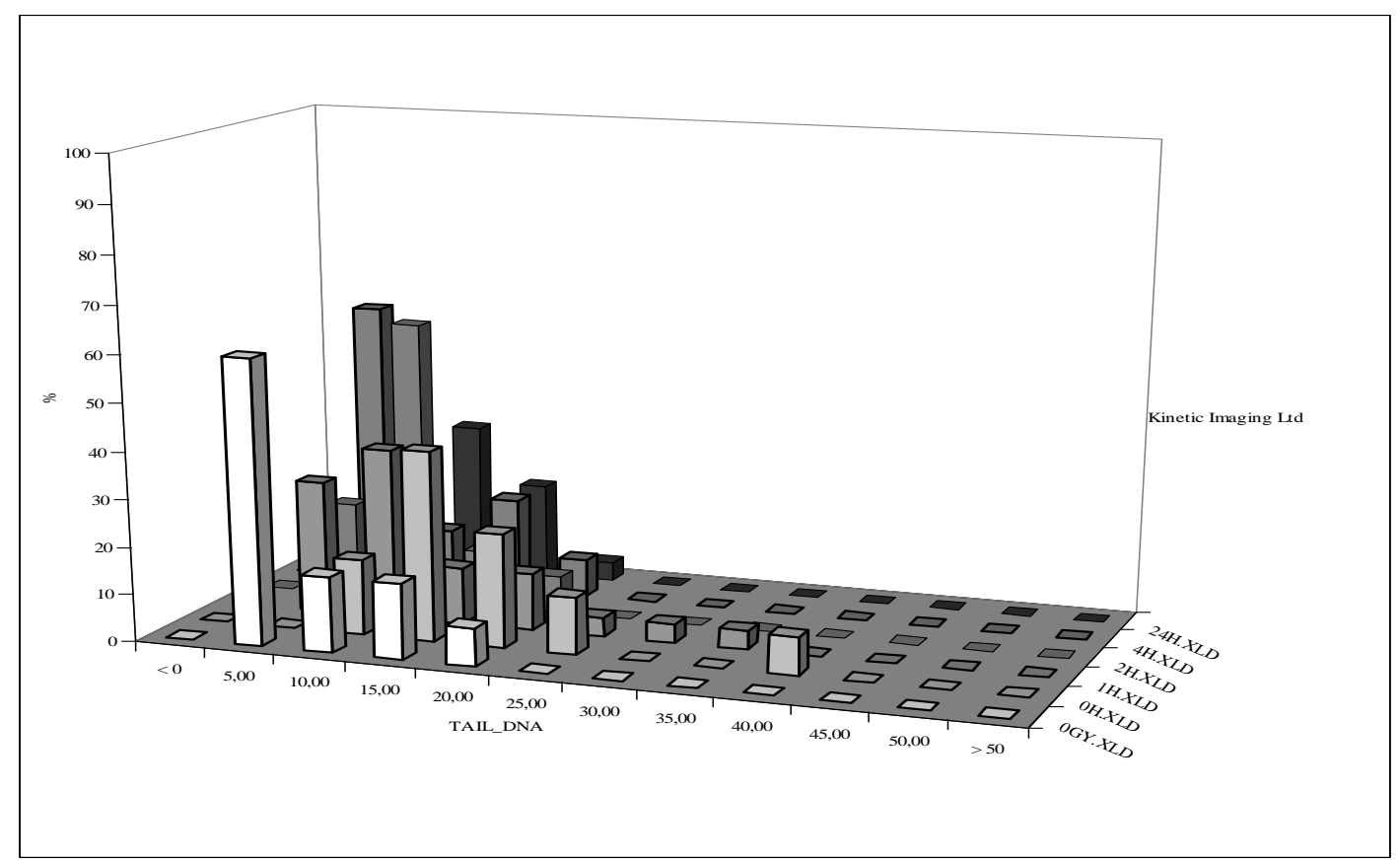

6. grafikon Kettős láncú DNS törések javításának időkinetikája 6 Gy-el besugarazott fibroblasztok esetén. Az első sorban a kezeletlen kontroll, a másodikban a sugárkezelést követően keletkező törések, majd 1-, 2-, 4 és 24 óra elteltével még jelen lévő, úgynevezett reziduális töréseket ábrázoltuk Kinetic Imaging program segítségével.

A sugárterápia következtében különböző sugárzás okozta mellékhatásokat elszenvedő betegek fibroblasztjait kezeltük 6Gy dózisú sugárzással in vitro, majd egy-sejt elektroforézissel vizsgáltuk az egy- és kétláncú DNS törésekből kifolyólag megjelenő DNS fragmentumok arányát. Adataink azt mutatják, hogy a kezelésre idegrendszeri toxikus mellékhatásokkal reagáló betegek fibroblasztjaiban több egyláncú DNS-törés keletkezik, mint a kontroll csoportban. Érdekes azonban, hogy mind a kontroll-, mind a súlyos mellékhatásokat szenvedett betegcsoportok fibroblasztjainak sejtmagvaiban gyakorlatilag maradéktalanul kijavítódnak ezek a törések. Jelen kísérleteinknek nem volt célja a javítás minőségéről információt biztosítani. A neutrális assay-vel nem találtunk szignifikáns összefüggést sem a primer, sem pedig a reziduális, 6 Gy-vel besugarazott fibroblasztok DNS-károsodásai valamint a megfelelő sejtvonalak SF2-értékei, vagy a betegek klinikai sugárérzékenysége (sugárkezelésre adott reakciói) között sem. Az adatok értékelésének statisztikai erejét további vizsgálatokkal lehetne emelni.

\begin{tabular}{|l|r|r|r|r|r|}
\hline Beteg kategória & \multicolumn{1}{|c|}{$\mathrm{pH}$} & \multicolumn{2}{|c|}{ OTM } & \multicolumn{2}{c|}{ Tail- DNA } \\
\hline & & \multicolumn{1}{c|}{ Oh } & \multicolumn{1}{c|}{$4 \mathrm{~h}$} & \multicolumn{1}{c|}{ h } & \multicolumn{1}{c|}{ h } \\
\hline \multirow{2}{*}{ Kontroll betegek } & 8,3 & 12,08 & 4,27 & 19,36 & 10,45 \\
\cline { 2 - 7 } & 13 & 22,97 & 3,90 & 33,48 & 10,70 \\
\hline $\begin{array}{l}\text { Idegrendszeri mellékhatásokat } \\
\text { szenvedett betegek }\end{array}$ & 8,3 & 12,98 & 3,23 & 18,74 & 9,21 \\
\cline { 2 - 6 } & 13 & 58,45 & 3,74 & 53,20 & 9,65 \\
\hline
\end{tabular}

1. táblázat 6 Gy-vel suggárkezelt fibroblasztok comet-assay eredményei: kezelés után közvetlenül (0h) és 4 órás javítódást követően (4h). A feltüntetett számok a betegek fibroblasztjain mért OTM és TailDNA értékek átlagait mutatják 


\section{Alkálikus és neutrális comet-assay alkalmazása vérmintákon a limfociták sugárérzékenységének kimutatására}

A fibroblasztokon végzett kísérletek meglehetősen időigényesek, mivel 2-4 hét alatt lehet létrehozni egy bőrbiopsziából fibroblaszt kultúrát, amelyet fenntartani és tenyészteni kell a kísérlet esedékességéig. Mivel a vérvétel egy jóval kevésbé invazív mintavételezési eljárás, és a vérből származó limfociták azonnal rendelkezésre állnak a kísérletekhez, a comet-assay kísérleteinket ugyanazon betegek limfocitáin is elvégeztük.

A DNS-törések alapszintjét alkálikus, és a neutrális comet-assay-vel vizsgáltuk besugarazatlan mintákon. Az alapszint adataink szerint gyakorlatilag nulla, nem függ a korábbi sugárterápiától. A betegekböl származó vérmintákat alkálikus comet-assay-hez $2 \mathrm{~Gy}$, neutrálishoz 4 Gy ${ }^{60} \mathrm{Co}$-gamma sugárzással kezeltük, és vizsgáltuk a közvetlenül a besugárzás után kialakuló DNS lánctöréseket (kezdeti károsodás), valamint a sugárkezelést követően négy órával még fennálló elváltozásokat (reziduális-, visszamaradó károsodás) is.

A sugárterápia következtében idegrendszeri mellékhatásokat mutató betegek esetében az in vitro besugárzás után közvetlenül, alkálikus comet-assay-vel nézve a DNS-károsodásokat, nem találtunk különbséget a kontroll csoporthoz viszonyítva. Négy órával a besugárzás után nézve a károsodásokat, az idegrendszeri mellékhatásokkal rendelkező betegeknél általában jóval több reziduális károsodás maradt vissza. Hasonló eredményeket kaptunk neutrális assay-vel is. Mucositis/dermatitises, valamint emlőtumoros betegeknél nem találtunk különbségeket egyik assay-vel sem a kontroll csoporthoz viszonyítva.

\begin{tabular}{|l|r|r|r|r|}
\hline \multicolumn{1}{|c|}{ Beteg kategória } & \multicolumn{2}{c|}{ OTM } & \multicolumn{2}{c|}{ Tail- DNA } \\
\hline & \multicolumn{1}{c|}{ Oh } & \multicolumn{1}{c|}{$4 \mathrm{~h}$} & \multicolumn{1}{c|}{ 0h } & \multicolumn{1}{c|}{$4 \mathrm{~h}$} \\
\hline Kontroll betegek & 44,07 & 17,86 & 38,27 & 22,15 \\
\hline $\begin{array}{l}\text { Idegrendszeri mellékhatásokat } \\
\text { szenvedett betegek }\end{array}$ & 41,43 & 23,33 & 37,71 & 26,32 \\
\hline $\begin{array}{l}\text { Mucositis vagy dermatitis tipusú } \\
\text { mellékhatásokat szenvedett betegek }\end{array}$ & 18,14 & 3,23 & 21,68 & 10,15 \\
\hline Emlődaganatban szenvedő betegek & 12,96 & 7,07 & 20,74 & 11,81 \\
\hline
\end{tabular}

2. táblázat 2 Gy-el besugarazott limfocitákban bekövetkező egyláncú törések ( $0 \mathrm{~h})$ és javítódásuk hatékonysága 4 óra múlva (átlagok).

\section{EREDMÉNYEK TÁRGYALÁSA ÉS KÖVETKEZTETÉSEK}

A fibroblaszt-minták SF2-értékeinek és a betegekben kialakuló toxikus sugár-reakcióknak az összevetésével kapott adatok azt valószínüsítik, hogy az SF2-értékek meghatározásával felbecsülhető a korai és késői toxikus sugárreakciók kialakulásának a kockázata. Azokban a betegekben, akiknek a fibroblasztjai sugárérzékenyek, sokkal nagyobb a valószínüsége a mellékhatások kialakulásának, mint a sugárrezisztenciát mutató fibroblasztokkal rendelkező betegek esetében. Előbbi betegek esetében kerülendő a szokásosnál nagyobb biológiailag effektív dózissal végzett sugárterápia és a sugármező a lehető legkisebb szükséges területre korlátozandó.

Véleményünk szerint eredményeink a munkahelyi sugárexpozíció eseteire is alkalmazhatók. Azok a személyek, akik a fibroblasztjainak túlélése az átlagosnál alacsonyabb tartományba esik (SF2<25\%-nál), a sztochasztikus (pl. daganat keletkezés) sugárhatások szempontjából egy jelentősebb kockázati csoporthoz tartoznak és az esetleges következmények korai diagnózisa érdekében fokozott megfigyelést igényelnek. 
A comet-assay módszere saját laboratóriumunk körülményei között alkalmas a sugárzás különböző dózisai által okozott és a javítás során visszamaradó DNS törések kimutatására.

Különbségek mutatkoznak a különböző mellékhatásokat szenvedett betegek limfocitáiban átlagosan visszamaradó egyláncú DNS törések mennyiségében 2 Gy besugárzás hatására, viszont jelenlegi álláspontunk szerint nincs meghatározó jellegű korreláció az egyes betegek limfocitáiban visszamaradó DNS sérülések és sugárterápiát követő klinikai mellékhatások között.

Annak ellenére, hogy 6 Gy besugárzást követően a kezdeti egyláncú DNS törések között igen jelentősnek tűnik a különbség az IR és a $\mathrm{K}$ betegek fibroblasztjai esetében, a DNS javító folyamatokat követően e két csoport közötti különbségek eltünnek. A klinikai sugárkezelésre változatos módon reagáló emlődaganatos betegekből származó, 4 Gy-vel sugárkezelt vérmintákban sem találtunk szignifikáns korrelációt a kétláncú DNS törések javítódása és a betegek klinikai mellékhatások között. Mivel a DNS által az agaróz gélen megtett távolság függ annak a molekuláris tömegétől, valószínü, hogy annak ellenére, hogy a törések mennyisége állandó, a letört DNS fragmentumok molekuláris tömegében mutatkozik különbség e két csoport között. Úgy tűnik, hogy nem a DNS törések mennyisége, hanem a helye és a javítódás minősége lehet meghatározó a sejt életvitele szempontjából. Mindazonáltal a betegekben kialakuló mellékhatások és DNS javító folyamataik minősége között fennálló összefüggések vizsgálatára ezen tanulmány nem terjed ki. A továbbiakban érdekes lenne egy olyan vizsgálatot folytatni, amely a DNS javító mechanizmusok mögött rejlő genetikai és molekuláris sajátosságok (génexpresszió, gén promoter metiláció, különböző fehérjék koncentrációja, stb.) közötti különbség vizsgálatát célozza meg a fent említett magasabb kockázatú betegcsoportokban. Eredményeink alapján ugyanis a két betegcsoport elhatárolható egymástól, de az egyéni klinikai sugár reakciók és a comet csóva DNS mennyisége, illetve e mennyiség repairt követő csökkenésének mértéke között nem sikerült szignifikáns kapcsolatot kimutatni.

Világszerte a comet-assay-t már genotoxitcitás-tesztelésére, humán biomonitorozásra, valamint különböző organizmusok ökogenotoxikológiai vizsgálatára használják. [16, 950. old.] Ennek ellenére, saját kísérleti körülményeink között úgy tünik, nem alkalmas egyéni különbségek meghatározására, hiszen annak ellenére, hogy valóban igen különböző eredményeket kaptunk az egyes egyének között (mintáink szórása igen magas értéket ért el), az egyének értékei és klinikai sugárreakciójuk között nem találtunk korrelációt. Hasonló eredményeket mutatnak be a hamburgi egyetem munkatársai 2001-ben megjelent cikkükben [11, 936. old.], ahol fordított korrelációt találtak a sejtek 2 Gy besugárzást követő túlélése és 5Gy besugárzás során keletkezett töredezett DNS mennyiség között, de nem találtak összefüggést a javítás után visszamaradt DNS mennyiség és a sugárérzékenység között. A csóvában található DNS fragmentumok mennyiségének jelentős eltérése közvetlenül a sugárkezelést követően a különböző betegcsoportokban arra utalhat, hogy a DNS molekuláris szerkezeti összetétele következtében egyes régiókban gyakrabban fordul elö kettős lánc törés.

A nemzetközi irodalomban nincs konszenzus a comet-assay sugárérzékenység-vizsgálatokra való alkalmasságát illetően. Eredményeink alátámasztják azt a feltételezést, miszerint a normál szövet radiotoxicitása a DNS javító rendszeren kívül több tényező függvénye. A jelenleg általánosan elfogadott paradigma értelmében a sugárzásra adott biológiai válasz olyan multimolekuláris folyamat, amelyben a résztvevő fehérjék gén-átíródásának, az epigenetikai folyamatoknak és a genom metilációs állapotának is számottevő szerepe van. [5, 613. old; 17, 1196-1198. old; 18] A továbbiakban az ezen folyamatokban szerepet játszó gének vagy fehérjék vizsgálata egy esetleges PCR- vagy antigén-antitest alapú módszer kidolgozásához vezethet. 


\section{FELHASZNÁLT IRODALOM}

[1] GY. KÖTELES (szerk.): Sugáregészségtan. Medicina Könyvkiadó RT., Budapest, 2002

[2] UNSCEAR: Exposures and effects of the Chernobyl accident, Annex J. 2000 Report to the General Assembly.

http://www.unscear.org/docs/reports/2000/Volume\%20II_Effects/AnnexJ_pages\%2045 1-566.pdf (2012.10.15)

[3] S. L. TUCKER, F. B. GEARA, L.J. PETERS, W. A. BROCK: How much could the radiotherapy dose be altered for individual patients based on a predictive assay of normal-tissue radiosensitivity? Radiotherapy and Oncology, 38 (1996) pp: 103-113, DOI: https://doi.org/10.1016/0167-8140(95)01669-4

[4] E. DIKOMEY, K. BORGMANN, I. BRAMMER, U. KASTEN-PISULA: Molecular mechanisms of individual radiosensitivity studied in normal human fibroblasts. Toxicology, 193 (2003) pp: 125-135, DOI: 10.1016/S0300-483X(03)00293-2

[5] W.U. MULlER, T. BAUCH, G. STÜBEN, H. SACK, C. STREFFER: Radiation sensitivity of lymphocytes from healthy individuals and cancer patients as measured by the comet assay. Radiat. Environ. Biophys., 40 (2001) pp: 83-89

[6] T.M. PAWLIK, K. KEYOMARSI: Role of cell cycle in mediating sensitivity to radiotherapy. Int. J. Radiation Oncology Biol. Phys., 59/4 (2004) pp: 928-942, DOI: https://doi.org/10.1016/j.ijrobp.2004.03.005

[7] M. BELLI, O. SAPORA, M. A. TABOCCHINI: Molecular targets in Cellular Response to Ionizing Radiation and Implications in Space Radiation Protection. J. Radiat. Res., 43 (2002) pp: S13-S19

[8] N.P. SINGH, M.T. MCCOY, R.R. TICE, E.L. SHNEIDER, A simple technique for quantitation of low levels of DNA damage in individual cells, in: Exp. Cell Res., 175 (1988) pp: 184-191, DOI: https://doi.org/10.1016/0014-4827(88)90265-0

[9] R.R. TICE, E. AQURELL, D. ANDERSON, B. BURLINSON, A. HARTMANN, H. KOBAYASHI, Y. MIYAMAE, E. ROJAS, J.C. RYU, Y.F. SASAKI: Single cell gel/Comet-assay: guidliness for in vitro and in vivo genetic toxicology testing. Environmental and Molecular Mutagenesis, 35 (2000) pp: 206-221

[10] D. BOWDEN, M.R. BUCKWALTER, J.F. MC BRIDE, D.A. JOHNSON, B.K. MURRAY, L. O'NEILL: Tail profile: a more accurate systemfor analyzing DNA damage using the Comet-assay. Mutation Research, 537 (2003) pp: 1-9, DOI: 10.1016/ $\underline{\text { S1383-5718(03)00056-1 }}$

[11] I. BRAMMER, M. ZOLLER, E. DIKOMEY, Relationship between cellular radiosensitivity and DNA damage measured by Comet-assay in human normal, NSB and AT fibroblasts. Int. J. Radiation Biology, 77/9 (2001) pp: 929-938, DOI: https://doi.org/10.1080/09553000110064222

[12] A. DASU, J. DENECAMP, Inducible repair and intrinsic radiosensitivity: a complex but predictable relationship? Radiation Research, 153 (2000) pp: 279-288, DOI: https:// doi.org/10.1667/0033-7587(2000)153[0279:IRAIRA]2.0.CO;2 
[13] E. DIEM, S. IVANCSITS, H.W. RUDIGER: Basal levels of DNA strand brakes in human leukocytes determined by comet-assay. J. Toxicol Environ Health A., 65/9 (2002) pp: 641-648, DOI: https://doi.org/10.1080/15287390252900331

[14] A. EJCHART, SADLEJ-SOSNOWSKA: Statistical evaluation and comparison of comet-assay results. Mutation research, 534 (2003) pp: 85-92, DOI: 10.1016/S1383$\underline{5718(02) 00250-4}$

[15] D. TWARDELLA, J. CHANG-CLAUDE: Studies on radiosensitivity from an epidemiological point of view - overview of methods and results. Radiotherapy and Oncology, 62 (2002) pp: 249-260, DOI: https://doi.org/10.1016/S0167-8140(01)00491$\underline{1}$

[16] A. AZQUETA, A. R. COLINS: The essential comet assay: a comprehensive guide to measuring DNA damage and repair. Arch. Toxicol., 87 (2013) pp:949-968, DOI: $\underline{10.1007 / \mathrm{s} 00204-013-1070-0}$

[17] E. DIKOMEY, K. BORGMANN, J. PEACOCK, H. JUNG: Why recent studies relating normal tissue response to individual radiosensitivity might have failed and how new studies should be performed. Int. J. Radiation Oncology Biol. Phys., 56/4 (2003) pp: 1194-1200, DOI: 10.1016/S0360-3016(03)00188-3

[18] M. FERNET, J. HALL: Genetic biomarkers of therapeutic radiation sensitivity. DNA Repair 3, (2004) pp: 1237-1243, DOI: 10.1016/j.dnarep.2004.03.019 